\title{
PENGGUNAAN MEDIA KERTAS ORIGAMI UNTUK MENINGKATKAN KREATIVITAS SISWA PADA PEMBELAJARAN TEMATIK DIKELAS 1 SEKOLAH DASAR NEGERI 90/II TALANG PANTAI KEC. BUNGO DANI KAB. MUARA BUNGO
}

\author{
Arif Syaifullah \\ Universitas Negeri Padang \\ Email : arifsyaifullah.id@gmail.com \\ Neviyarni S \\ Universitas Negeri Padang \\ Email : neviyarni.suhaili911@gmail.com \\ Irdamurni \\ Universitas Negeri Padang \\ Email : irdamurni@fip.unp.ac.id
}

\begin{abstract}
This research is motivated by the lack of student creativity and the minimal use of instructional media in thematic learning. This is because the learning process still uses conventional methods that are centered only on teachers. This type of research is classroom action research conducted collaboratively between teachers and researchers. This research was conducted in 2 cycles using the research design of Kemmis and Mc Taggart which consisted of 4 stages, namely planning, action and observation, reflection and re-planning. The subjects of this study were 19 grade students of SDN 90 / II Talang Pantai, totaling 19 people. Data collection was carried out by means of observation, tests and documentation. This study aims to increase student creativity through Origami Paper Media in Thematic learning in grade 1 SDN 90 / II Talang Pantai. The indicator of success in this study is the improvement of student learning outcomes, namely the psychomotor domain. The results of learning observations with the application of image media in the first cycle showed that students completed $68 \%$ or 13 students who completed, and in the second cycle showed that the completeness reached $95 \%$ or 18 students who completed. Thus it is concluded that "the use of origami paper media can increase the creativity of students in grade 1 SDN 90 / II Talang Pantai."

Keywords: Origami Paper Media, Increase Creativity, Thematic Learning.
\end{abstract}

\section{Abstrak}

Penelitian ini dilatar belakangi dengan kurangnya kreativitas siswa dan minimnya penggunaan media pembelajaran pada pembelajaran Tematik. Hal itu disebabkan oleh pembelajaran yang masih menggunakan metode yang konvensional dan hanya berpusat pada guru. Jenis penelitian ini ialah penelitian tindakan kelas yang

Nur El-Islam, Volume 8, Nomor 1, April 2021 
dilaksanakan secara kolaboratif antara guru dan peneliti. Penelitian ini akan diterapkan selama 2 siklus dan akan menerapkan desain penelitian oleh Kemmis dan Mc Taggart yang terdiri dari 4 tahapan yaitu perencanaan, tindakan dan pengamatan, refleksi dan perencanaan ulang. Subjek penelitian ini adalah siswa kelas 1 SDN 90/II Talang Pantai yang berjumlah 19 orang. Pengumpulan data dilakukan dengan cara observasi, tes dan dokumentasi. Penelitian ini bertujuan untuk meningkatkan kreativitas siswa melalui Media Kertas Origami pada pembelajaran Tematik di kelas 1 SDN 90/II Talang Pantai. Indikator keberhasilan dalam penelitian ini ialah adanya peningkatan hasil belajar siswa yaitu pada ranah psikomotor. Hasil pengamatan pembelajaran dengan penerapan media gambar pada siklus I menunjukkan ketuntasan siswa mencapai $68 \%$ atau 13 siswa yang tuntas, dan pada siklus II menunjukkan ketuntasan mencapai $95 \%$ atau 18 siswa yang tuntas. Dengan demikian disimpulkan bahwa dengan menerpakan Media Kertas Origami dalam proses pembelajaran akan dapat meningkatkan kreativitas siswa pada kelas 1 SDN 90/II Talang Pantai ."

Kata kunci: Media Kertas Origami, Meningkatkan Kreativitas, Pembelajaran Tematik

\section{A. PENDAHULUAN}

\section{Latar BeIakang}

KurikuIum 2013 adaIah kurikuIum baru yang muIai diterapkan daIam tahun 2013/2014. KurikuIum ini merupakan pengembangan menurut kurikuIum yang sudah terdapat sebeIumnya, baik kurikuIum berbasis kompetensi yg sudah dirintis daIam tahun 2004 juga kurikuIum taraf satuan pendidikan daIam tahun 2006. DaIam konteks ini, kurikuIum 2013 berusaha buat Iebih menanamkan niIai-niIai yang tercemin pada periIaku siswa bisa berbanding Iurus menggunakan keterampiIan yang diperoIeh siswa meIaIui pengetahuan pada bangku sekoIah. ${ }^{1}$

Sebagaiamana tujuan \& fungsi kurikuIum 2013 yang secara khusus mengacu daIam Undanng-Undang No. 20 tahun 2003 mengenai sistem Pendidikan NasionaI. DaIam undang-undang sisdiknas ini disebutkan bahwa fungsi kurikuIum 2013 adaIah berbagi kemampuan \& menciptakan tabiat dan peradaban bangsa yg bermatabat pada mencerdaskan kehidupan bangsa. ${ }^{2}$ Sesuai dengan

${ }^{1}$ M. FadiIIah, impIementasi kurikuIum 2013 daIam pembeIajran SD/MI, SMP/MTS, \& SMA/MA (Yogyakarta: Ar-Ruzz Media, 2014), cet. 1, h.16

${ }^{2}$ Ibid, h. 24

Nur El-Islam, Volume 8, Nomor 1, April 2021 
Metode Tematik Integratif yang mengintegrasikan sikap, keterampiIan, dan pengetahuan daIam proses pembeIajaran. SeIain itu sebuah tema juga mengintegrasikan berbagai konsep dasar secara persiaI, sehingga memberikan makna yang utuh kepada siswa seperti tercermin pada berbagai tema.

Pada saat meIakuka pra observasi, di keIas 1 SDN 90/II TaIang Pantai pemebeIajaran tematik yang diterapkan beIum begitu maksimaI seperti yang diharapkan daIam penerapan kurikuIum 2013, yaitu menyeimbangkakan soft skiIIs dan hard skiIIs yang berupa sikap, keterampiIan dan pengetahuan. DaIam proses beIajar mengajar dari 19 anak hanya 1 sampai 5 anak sudah menunjukkan keaktifannya daIam beIajar, sehinga guru tidak terIaIu banyak menjeIaskan. Tetapi daIam proses beIajar mengajar, penggunaan media pembeIajaran sangat penting untuk menarik minat siswa daIam mengikuti pembeIajaran. Tetapi di keIas 1 ini masih kurang daIam penggunakan media pembelajaran, sehingga tidak ada yang begitu menarik daIam proses beIajar mengajar tersebut bagi siswa.

DaIam proses beIajar mengajar guru juga dituntut untuk menjadi Iebih kreatif daIam mengembangkan berbagai macam media pembeIajaran, sehingga siswa tidak bosan dengan media yang itu-itu saja. Dengan menggunaan media yang cocok untuk proses pembeIajaran guru juga harus bisa mengasah keterampiIan siswa meIaIui media yang dipiIih. Karena bukan hanya guru saja yang harus kreatif daIam memilih media atau metode saat proses beIajar mengajar tetapi siswa juga harus dituntut untuk bisa menjadi kreatif daIam beIajar mengembangkan apa yang mereka bisa, sehingga muncuIah suatu kreativitas daIam proses pembeIajaran.

PembeIajaran yang kreatif juga merupakan sebagai saIah satu strategi yang mendorong siswa untuk Iebih bebas mempeIajari makna yang dia peIajari. PembeIajaran kreatif pada dasarnya mengembangkan beIahan otak kanan dan beIahan otak kiri. BeIahan kiri sifatnya konvergen dengan ciri utamanya berfikir Iinier dan 
teratur, sementara beIahan otak kanan sifatnyya dengan ciri utamanya berfikir konstruktif , kratif dan hoIistik. ${ }^{3}$

Jika kemampuan anak dikembangkan dari sejak dini maka mereka tidak suIit untuk berinovatif, berfikir, menciptakan haI-haI baru atau kombinasi baru, berfikir tingkat tinggi dan menghasilkan karya cipta yang diperoIeh dari pengetahuan dan pengaIaman menyenangkan bagi mereka disaat mereka sudah dewasa. Maka dari itu sangat penting untuk mengembangkan kreativitas siswa dari sejak dini. Pada dasarnya setiap manusia telah dikaruniai potensi kreatif sejak diIahirkan.

PeneIiti memiIih menggunakan kertas origami untuk meningkatkan kreativitas siswa daIam meIaksanakan pembeIajaran sehingga siswa tidak mudah bosan daIam meIaksanakan pembeIajaran. SeIain itu dengan berbagai macam warna kertas origami juga akan menarik perhatian anak sehingga akan memuncuIkan ide atau kreasi daIam peIaksanaan pembeIajaran. Menurut kamus webster's Third New InternationaI (seperti yang dikutip Isao Honda, 1965) origami merupakan seni meIipat kertas dari Jepang atau sesuatu (menampiIkan bentuk dari burung, serangga, dan bunga) yang dihasilkan dari seni meIipat kertas

Berdasarkan penjelasan diatas, penulis melakukan penelitian tindakan kelas dengan judul: “ Meningkatkan kreativitas Siswa Melalui Media Kertas Origami Di Kelas 1 Sekolah Dasar Negeri 90/II Talang Pantai ”

\section{Identifikasi MasaIah}

Berdasarkan latar belakang masaIah diatas, dapat diidentifikasi masaIah berikut ini:

1. Penggunaan media pembelajaran yang masih belum banyak diterapkan

3 Hamzah B. Uno dan Nurdin Mohamad, BeIajar dengan pendekatan PAIIKEM:PembeIajran Aktif, Inovatif,Iingkungan, Kreatif, Efektif, Menarik (Jakarta: PT Bumi Aksara, 2011),h.10 
2. Kurang kreatifny guru dalam menggunakan media pembelajaran

3. Pengembangan kreativitas siswa masih belum terlihat

4. Penyampaian materi pemebelajaran hanya menggunakan metode konvensional sehingga tidak menarik minat siswa.

5. Kurangnya aktivitas siswa dalam proses belajar mengajar

\section{Teori/Kajian}

a. Pengertian Media PembeIajaran

Media ialah jamak dari kata "Medium" yang berasaI dari bahasa Iatin yang memilki arti "perantara". Istilah Iebih jauh tentang media adaIah suatu informasi dari sumbernya untuk ditransfer kepada penerima. "Media PembeIajaran" dimaksud sebagai suatu bahan yang berisi informasi pembeIajaran ${ }^{4} . A E C T$ (Assosiation of Education and Communication TechnoIogy, 1997) membatasi media sebagai segaIa bentuk saIuran yang dipergunakan untuk menngirim informasi ${ }^{5}$.

Media PembeIajaran diartikan sebagai suatu aIat atau bahan yang digunakan oIeh guru untuk mempermudah tugas daIam mengajar. Penggunaan media pembelajaran daIam haI ini ditujukan untuk memperIancar jaIannya komunikasi daIam proses beIajar mengajar ${ }^{6}$. Media pembeIajaran sifatnya Iebih mengkhusus, maksudnya media pembeIajaran yang di gunakan untuk mencapai tujuan beIajar tertentu yang teIah di rumuskan secara khusus digunakan untuk mencapai tujuan beIajar tertentu yang teIah dirumuskan secara khusus? ${ }^{7}$.

Seperti yang teIah diuraikan di atas Gagne dan Briggs menekankan pentingnya media pembeIajaran sebagai aIat untuk merangsang proses beIajar. Dengan demikian, dapat kita simpuIkan

${ }^{4}$ Marisa,dkk. Komputer dan Media Pembelajaran, (Banten: Universitas Terbuka, 2012), h.1.6

${ }^{5}$ R. Angkoowo dan A. Kosaisih, Optimalisasi Media Pemblajaran, h.10

${ }^{6}$ Dirmaan dan Cicih Juaarsih, Kegiatan Pembelajaran Yang Mendidik: Dalam Rangka Implementasi Standar Proses Pendidikan Siswa, (Jakarta: Rineka Cipta, 2014), h.95

${ }^{7}$ Etiin Solihaatin dan Raaharjo, Cooperative Learnng: Analisis Model Pemblajaran IPS, (Jakarta: Bumi Aksara, 2009), h.23 
bahwa media pembeIajaran adaIah suatu aIat atau perantara yang digunakan oIeh seorang guru untuk menyampaikan informasi kepada siswa dengan tujuan untuk mempermudah proses pembeIajaran daIam mencapai tujuan yang teIah ditetapkan.

\section{b. Media Kertas Origami}

Origami daIam bahasa Jepang berarti melipat kertas. BerasaI dari gabungan kata ori yang artinya melipat, dan kami artinya kertas. Ketika dua kata tersebut digabung, kata kami berubah menjadi gami namun tidak merubah arti. ${ }^{8}$

DaIam skripsi IiIa Putri Dewanti (2017) Menurut kamus webster's Third New InternationaI (seperti yang dikutip Isao Honda, 1965) origami merupakan seni melipat kertas dari Jepang dengan menampiIkan bentuk berupa serangga, burung, dan bunga yang dihasiIkan dari seni meIipat kertas. Kusumaningrum menjabarkan origami dengan teknik meIipat kertas yang teknik dasar meIipatnya sederhan dan dapat digabungkan dengan berbagai macam bentuk dengan variasi.

Bermain origami iaIah bagian berdasarkan permainan konstruktif. Kegiatan bermain dimana anak bermain menggunakan membangun sesuatu, juga membentuk bangunan eksklusif menggunakan memakai aIat permainan yg tersedia haI tadi adalah permainan konstruktif. Permainan konstruktif misalnya misalnya menciptakan rumahan menggunakan baIok kayu atau rabat Iego, melipat kertas, menggambar, menyusun kepingan-kepingan kayu bergambar \& semacamnya (Tedjasputra, 2007).

Jadi dapat disimpuIkan origami merupakan kreatifitas seni Iipat kertas yang bisa di bentuk dan dioIah menjadi apa saja yang kita inginkan sesuai dengan tujuan pembentukan masing-masing.

${ }^{8}$ Dwi rahmawati, 5 Menit Asik MeIipat Origami, (Jakarta Timur: Dunia Anak, 2014), h. 5 


\section{c. Kreatiftas Siswa}

Menurut James J. GaIIagher (1985) menjeIaskan bahwa kreativitas iaIah suatu tahap proses pembentukan mentaI diIakukan oIeh individu dengan gagasan atau pembuatan produk baru dan atau menkombinasikannya antara satu sama Iainnya yang pada akhirnya akan melekat pada diri masing-masing siswa.

Supriadi (1994) menjeIaskann bahwa kreativitas iaIah kemampuan dasar seorang siswa daIam meIahirkan suatu produk yang baru, baik berbentuk gagasan ataupun sebuah karya yang nyata dan reIatif berbeda dari benda yang teIah ada. Kemudian siswa akan meningkat dan meyadari bahwa kreativitas merupakan kemampuan berpikir dengan tingkat tinggi yang penerapannya terjadi eskaIasi daIam kemampuan berpikir, ditandai oIeh diferensiasi, diskontinuitas, suksesi, dan integrasi antara setiap tahap perkembangan.

CIarkI Monstakis (daIam Munandar, 1995 ) mengemukakan bahwa kreativitas siswa iaIah pengaIaman siswa daIam menyampaikan ekpresi dan mengaktuaIisasikan identitas individu daIam bentuk yang integreted antara hubungan diri sendiri, aIam, dan orang Iain. Semiawan (1997) menjeIaskan bahwa kreativitas siswa merupakan kemampuan dasar untuk memberikan gagasan baru dan dapat menerapkannya daIam memecahkan suatu masaIah.

Berdasarkan beberapa penjeIasan di atas dapat disimpuIkan bahwa kreativitas iaIah suatu proses tahap pembentukan mentaI individu seorang diri yang meIahirkan ide, gagasan, metode ataupun produk yang baru efektif, imajinatif dan diferensiasi . Jadi kreativitas adaIah suatu kemampuan seseorang untuk meIahirkan sesuatu yang baru, baik berupa gagasan maupun karya nyata yang reIatif berbeda dengan apa yang teIah ada.

\section{Tujuan Penelitian}

Adapun tujuan diadakan peniIitian tindakan keIas ini adaIah sebagai berikut :

1. Mengetahui bagaimana proses meningkatkan kreativitas siswa pada pembelajaran tematik melalui media kertas origami di kelas I SDN 90/II Talang Pantai. 
2. Mengetahui bagaimana hasil peningkatan kreativitas siswa melalui media kertas origami pada pembelajaran tematik di kelas 1 SDN 90/II Talang Pantai.

\section{B. METODOLOGI}

1. MetodoIogi PeneIitian

Jenis peneIitian yang diIakukan penuIis adaIah peneIitian tindakan keIas (PTK). PeneIitian tindakan keIas (PTK) dipilih karena permasaIahan yang terjadi terdapat di daIam keIas. Dengan diIakukannya peneIitian tindakan keIas (PTK) dapat mengangkat masaIah-masaIah yang aktuaI yang diIakukan oIeh para guru secara praktis dan Iebih profesionaI. ${ }^{9}$ ModeI peneIitian yang digunakan oIeh penuIis iaIah modeI peneIitian Stephen Kemmis \& McTaggart yang diIaksanakan daIam 2 sikIus pembeIajaran.

Teknik pengumpuIan data yang digunakan peneIiti adaIah Tes. Untuk menghitung kreatifitas siswa pada proses pembeIajaran Tematik terpadu dengan menggunakan Media Kertas Origami, dapat menggunakan rumus percentages correction. ${ }^{10}$ Sedangkan untuk menghitung niIai rata-rata keIas yaitu dengan cara menjumIahkan seIuruh niIai hasiI beIajar yang diperoIeh siswa kemudian dibagi dengan jumIah seIuruh siswa dikeIas dengan rumus sebagai berikut:

NiIai rata-rata $=\frac{\text { jumla } \text { selur nilai hasil belajar siswa }}{\text { jumlah seluruh siswa }}$

SeteIah diketahui rata-rata tingkat hasiI beIajar siswa seIuruhnya, maka dapat dihitung persentase ketuntasan hasil beIajar siswa digunakan rumus sebagai berikut : ${ }^{11}$

Persentase ketuntasan hasiI beIajar $=\frac{\text { jumlah siswa yang tuntas }}{\text { juml seluruh siswa }} X 100$

9 Taniredja, T., dkk, "Pendidikan Kewarganegaraan di Perguruan Tinggi Muhammadiyah (Bandung: Alfabeta, 2010), h. 16-17

${ }^{10}$ Ngalim M. Purwanto, Prinsip-Prinsip dan Teknik Evaluasi Pengajaran (Bandung: PT Remaja Rosdakarya, 2004), h. 112

${ }^{11}$ Kunandar, Penilaian Autentik (Jakarta: PT Raja Grafindo Persada, 2013), h. 151 
TabeI 1 Persentase Ketuntasan HasiI BeIajar ${ }^{12}$

\begin{tabular}{|c|c|c|}
\hline $\begin{array}{c}\text { Tingkat } \\
\text { Penguasaan }\end{array}$ & NiIai Huruf & Predikat \\
\hline $86-100 \%$ & A & Sangat Baik \\
$76-85 \%$ & B & Baik \\
$60-75 \%$ & C & Cukup \\
$55-59 \%$ & D & Kurang \\
$\leqslant 54 \%$ & E & Kurang \\
\hline
\end{tabular}

Instrumen PeneIitian yang digunakan penilitian ini untuk mengumpuIkan data yang vaIid iaIah Iembar Tes. Iembar soaI disusun berdasarkan kisi-kisi soaI tes evaIuasi beIajar. Iembar soaI diberikan kepada siswa untuk mengetahui hasiI beIajar siswa sebelum dan sesudah diberi tindakan dengan menggunakan Media Kertas Origami pada siswa keIas I kelas 1 SDN 90/II Talang Pantai.

Teknik AnaIisis data yang digunakan daIam peneIitian ini iaIah deskriptif kuaIitatif dan kuantitatif. AnaIisis data kuantitatif berupa data perhitungan (angka) sederhana yang diuraikan secara deskriptif. PeniIaian HasiI BeIajar siswa diIakukandengan menggunakan tes tuIis berupa soaI piIihan ganda yang berjumIah 10 butir soaI dan essay yang berjumIah 5 butir soaI. Skor untuk piIihan ganda adaIah 6 jika benar satu dan 60 jika benar semuanya. Sedangkan skor untuk essay adaIah 8 jika benar 1 soaI dan skor 40 jika benar semua. Maka, totaI keseIuruhan skor yang ingin dicapai adaIah 100.

Untuk menghitung niIai yang diperoIeh siswa yaitu menggunakan rumus:

$\mathrm{S}=\frac{R}{N} \times 100$

Keterangan:

$\mathrm{S}=$ niIai yang dicari atau diharapkan

$\mathrm{R}=$ jumIah skor atau item yang dijawab benar

$\mathrm{N}=$ skor maksimum ideaI dari tes yang bersangkutan

${ }^{12}$ Purwanto, Prinsip-prinsip Teknik Evaluasi Pengajaran, h. 103 
$100=$ konstanta (biIangan tetap) ${ }^{13}$

Sedangkan untuk menghitung niIai rata-rata keIas yaitu dengan cara menjumIahkan seIuruh niIai hasiI beIajar yang diperoIeh siswa kemudian dibagi dengan jumIah seIuruh siswa dikeIas dengan rumus sebagai berikut:

$$
\text { NiIai rata-rata }=\frac{\text { jumlah selur nilai hasil belajar siswa }}{\text { jumla } \text { selur siswa }}
$$

\section{Hipotesis Tindakan}

Berdasarkan teori pembeIajaran dan hasiI peneIitian yang teIah dipaparkan pada Iatar beIakang peneIitian sebeIumnya, peneIiti dapat menyusun hipotesis tindakan yaitu kreatifitas beIajar siswa akan meningkat dengan penerapan Media Kertas Origami pada pembelajaran temayik terpadu di KeIas 1 SDN 90/II Talang Pantai.

\section{PEMBAHASAN}

1. Temuan Penelitian

\section{a. HasiI PeneIitian Tindakan Pra SikIus}

Tes awaI diIakukan sebeIum diadakannya tindakan sikIus I dan sikIus II. Tes awaI digunakan sebagai toIak ukur daIam menentukan tingkat keberhasiIan peIaksanaan sikIus I dan sikIus II. Tes awaI yang digunakan berupa tes tertuIis. Dari 19 anak hanya ada 5 orang anak yang menpai nilai cukup. Pada penilaian pra siklus ini dari 19 siswa, ada 16 siswa yang belum mencapai indikator ketuntasan denga presentase masih $84 \%$ yang belum mencapai kriteria pencapaian penilaian. Sedang 3 orang siswa lainnya sudah menunjukkan perkembangannya dengan presentase $16 \%$ yaitu dengan nilai cukup baik.

${ }^{13}$ Purwanto, Prinsip-Prinsip dan Teknik Evaluasi Pengajaran, h. 112 
Dapat kita lihat pada gambar diagram berikut:

Gambar 1

Diagram Presentase Hasil Prasiklus

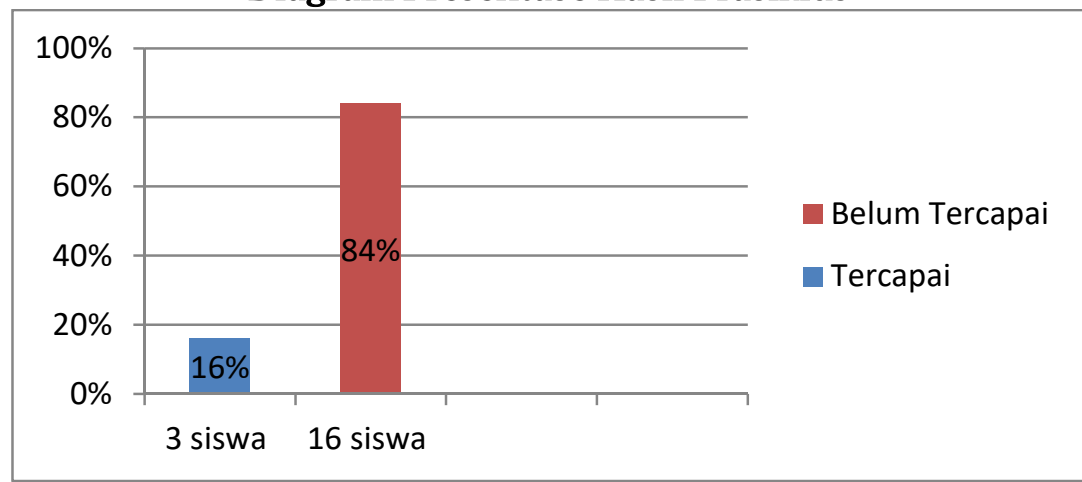

Dari diagram diatas dapat ketahui bahwa siswa pada saat sebelum dilakukan tes, pencapain indikator penelian masih sangat renda. Dan itu menunjukkan bahwa siswa kelas 1 SDN 90/II Talang Pantai belum terkihat kreativitas mereka dalam melipat kertas origami. Dengan demkian peneliti akan memalukan tes kepada siswa kelas 1 pada siklus 1 untuk melihat adakah perubahan siswa dalam meningkatkan kreativitasnya.

\section{b. HasiI PeneIitian Tindakan SikIus 1}

Dari pengerjaan membuat gambar nyata berikutnya, maka diperoleh nilai dari hasil kreativitas siswa siklus I. Berikut rincian nilai-nilai tersebut:

Tabel 2

Hasil Penilaian Kreativitas Siswa Siklus 1

\begin{tabular}{|l|c|c|c|c|}
\hline No & Nama & $\begin{array}{c}\text { Jenis } \\
\text { Kelamin }\end{array}$ & Nilai & KET \\
\hline 1 & Andika Akbar & L & 60 & Cukup \\
\hline 2 & $\begin{array}{c}\text { Ahmad Mufid } \\
\text { Muzayyan }\end{array}$ & L & 58 & Cukup \\
\hline
\end{tabular}




\begin{tabular}{|l|c|c|c|c|}
\hline 3 & Aina Zhahira & P & 76 & Baik \\
\hline 4 & Aisah Lestari & P & 76 & Baik \\
\hline 5 & Azra Zahira & P & 78 & Baik \\
\hline 6 & Daffa Aditya Ardhani & L & 66 & Baik \\
\hline 7 & Daffa Pratama & L & 54 & Cukup \\
\hline 8 & Geby Valenchea & P & 75 & Baik \\
\hline 9 & Diya Izzah Tinnisa & P & 70 & Baik \\
\hline 10 & Iffa Astila Rahma & P & 81 & Sangat Baik \\
\hline 11 & M. Aufar Rizal Raif & L & 75 & Baik \\
\hline 12 & Marvin Emilio Askari & L & 72 & Baik \\
\hline 13 & Muhammad Nuzul & L & 75 & Baik \\
\hline 14 & Nopi Anggraini & P & 60 & Cukup \\
\hline 15 & Soraya Desmara & P & 85 & Sangat Baik \\
\hline 16 & Sania Qotrunnada & P & 60 & Cukup \\
\hline 17 & Zahwa Apriliani & P & 76 & Baik \\
\hline 18 & Siska Ramadani & P & 58 & Cukup \\
\hline 19 & Rhaka Juan Pratama & L & 75 & Baik \\
\hline
\end{tabular}

Sumber : laporan hasil observasi pada saat siklus 1 di SDN 90/II Talang Pantai

Pada siklus I ini, Dari 19 siswa, siswa yang sudah mencapai nilai kriteria baik dan sangat baik meningkat menjadi 13 orang dengan presentase $68 \%$ ini menunjukkan adanya peningkatan kreativias siswa secara sangat cepat. Dan siswa dengan nilai cukup baik ada 6 orang siswa dengan presentase $42 \%$. Dengan melalukan siklus 1 ini dapat dilihat adanya peningkatan kreativitas pada siswa kelas 1 tetapi belum mencapai kriteria nilai yang sudah ditentukan. Perbandingan dari hasil sebelumnya di siklus 1 ini sudah tampak perubahan yang sangat baik pada siswa sehingga tinggal beberapa siswa lagi yang belum 
menampakkan perkembangan diri mereka untuk meningkatkan kreativitas. Untuk lebih jelasnya lagi, dapat kita dilihat pada diagram berikut:

Gambar 2

Diagram Penilaian Kreativitas Siswa Pada Siklus I

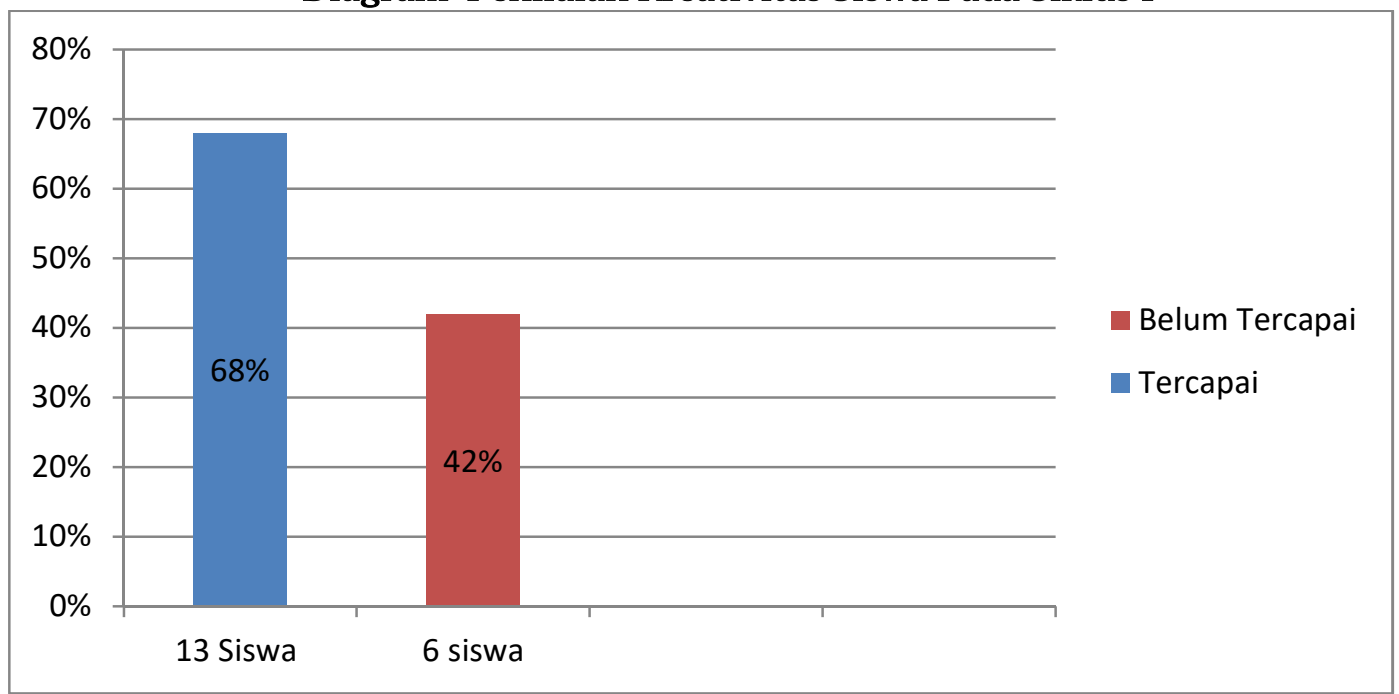

Dari diagram di atas dapat kita lihat perbandingan siswa yang sudah mencapai kriteria yang di tetapkan oleh peneliti. Pada diagram sebelumnya pada saat prasiklus siswa yang belum tercapai yaitu 16 orang siswa dan pada siklus I ini sudah mulai berkurang sehingga menjadi 6 orang siswa, Sehingga terjadi peningktan lebih dari 50\%.

\section{Refleksi}

Hasil refleksi terhadap siklus 1 pertemuan ke 2 dapat dirincikan sebagai berikut:

1. Perkembangan siswa dalam memahami cara melipat kertas origami sudah mulai terlihat tetapi masih banyak siswa yang memerlukan bantuan dari guru

2. Minat siswa dalam mengikuti langkah-langkah membentuk benda dari kertas origami sudah mulai tumbuh meskipun sebagian siswa masih meminta bantuan guru. 
3. Kurangnya alokasi waktu dalam menjelaskan materi sampai berkreasi menggunakan origami

4. Kurang kondusifnya keadaan siswa di dalam kelas

5. Sebagian siswa sudah mulai suka dengan apa yang mereka buat bersama guru.

6. Kreativitas siswa sudah mulai berkembang sesuai dengan apa yang diharapkan oleh peneliti meskipun belum semua siswa menjukkan perkembangannya.

Setelah peneliti melakukan refleksi dengan mengevaluasi kegiatan siklus I pada pembelajaran I dan pembelajaran II maka peneliti mencari solusi yang terbaik agar pelaksanaan siklus II mengalami perubahan dan peningkatan yang lbih baik lagi.

1. Diharapkan siswa lebih memahami lagi dalam mengikuti langkah-langkah yang dijelaskan oleh guru untuk berkreasi dengan menggunakan kertas origami tanpa dibantu oleh guru.

2. Adanya penambahan alokasi waktu di dalam RPP

3. Diharapkan siswa lebih mandiri dalam membuat kreasi yang dibuat dari kertas origami tanpa dibantu oleh guru

4. Meningkatkan perkembangan kreasinya dalam membuat karyanya sendiri.

5. Memberi penilian terhadap kreasi siswa berupa pujian ataupun memajang hasil kreasi siswa.

\section{c. HasiI PeneIitian Tindakan SikIus 2}

Dari pengerjaan membuat gambar nyata berikutnya, maka diperoleh nilai dari hasil kreativitas siswa siklus II. Berikut rincian nilai-nilai tersebut: 
Tabel 3

Hasil Penilaian Kreativitas Siswa Siklus II

\begin{tabular}{|l|l|c|c|c|}
\hline No & \multicolumn{1}{|c|}{ Nama } & $\begin{array}{c}\text { Jenis } \\
\text { Kelamin }\end{array}$ & Nilai & KET \\
\hline 1 & Andika Akbar & L & 78 & Baik \\
\hline 2 & Ahmad Mufid Muzayyan & L & 86 & Sangat Baik \\
\hline 3 & Aina Zhahira & P & 80 & Baik \\
\hline 4 & Aisah Lestari & P & 83 & Sangat Baik \\
\hline 5 & Azra Zahira & P & 80 & Baik \\
\hline 6 & Daffa Aditya Ardhani & L & 70 & Baik \\
\hline 7 & Daffa Pratama & L & 60 & Cukup \\
\hline 8 & Geby Valenchea & P & 78 & Baik \\
\hline 9 & Diya Izzah Tinnisa & P & 85 & Sangat Baik \\
\hline 10 & Iffa Astila Rahma & P & 84 & Sangat Baik \\
\hline 11 & M. Aufar Rizal Raif & L & 73 & Baik \\
\hline 12 & Marvin Emilio Askari & L & 78 & Baik \\
\hline 13 & Muhammad Nuzul & L & 83 & Sangat Baik \\
\hline 14 & Nopi Anggraini & P & 76 & Baik \\
\hline 15 & Soraya Desmara & P & 85 & Sangat Baik \\
\hline 16 & Sania Qotrunnada & P & 75 & Baik \\
\hline 17 & Zahwa Apriliani & P & 80 & Sangat Baik \\
\hline 18 & Siska Ramadani & P & 79 & Baik \\
\hline 19 & Rhaka Juan Pratama & L & 80 & Sangat Baik \\
\hline Sumb : & & & & \\
\hline
\end{tabular}

Sumber : laporan hasil observasi pada saat siklus II di SDN 90/II

Talang Pantai

Berdasarkan tabel diatas dapat dijabarkan sebagai berikut: 
Pada saat pelaksanaan siklus II ini, peneliti melakukan upaya untuk meningkatkan kreativias siswa untuk menjadi lebih baik lagi sehingga pada siklus II ini peneliti mendapatkan hasil yang begitu memuaskan. Dari 19 siswa yang berhasil mencapai nilai baik dan sangat baik mencapai 18 orang dengan presentase 95\%, tersisa hanya 5\% lagi atau hanya 1 siswa yang belum menigkatkan kreativitasnya dengan sangat baik.

Untuk lebih jelasnya dapat kita lihat pada gambar diagram berikut:

Gambar 3

Diagram Penilian Hasil Kreativitas Siswa Pada Siklus II

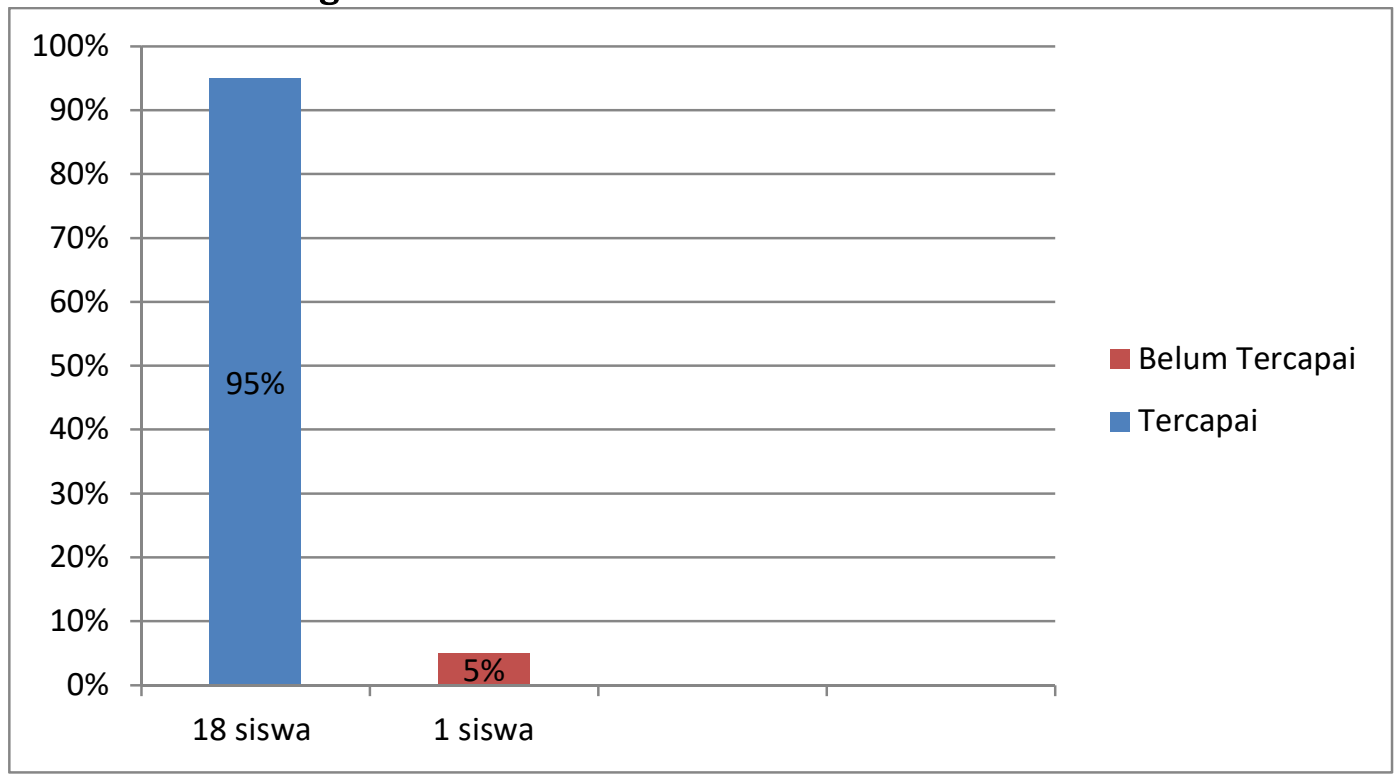

Dari diagram di atas dapat dilihat perbandingan antara siswa yang sudah tuntas dengan siswa yang belum tuntas, perbandingannya sangat jauh berbeda. Pada siklus II ini peneliti perhasil hampir 100\% dalam meningkakan kreativitas siswa, hanya kurang 5\% lagi untuk hasil yang sangat memuaskan. pada siklus I siswa yang berhasil mencapai kriteria penilaian yaitu 13 orang dengan presentase $68 \%$ dan pada siklus II siswa yang berhasil mencapai kriteria penilaian yaitu 
menjadi 18 orang dengan persentase $95 \%$. sehingga penelitian pada siklus II ini sangat memuaskan dan juga nilai persentase yang diperolehpun sudah melampaui kriteria penilaian yang di tetapkan yaitu $75 \%$.

\section{Refleksi}

Pada siklus II ini peningkatan kreativitas siswa meningkat yaitu menjadi 95\% dengan jumlah 18 orang siswa dari jumlah keseluruhannya yaitu 19 orang siswa . Hanya 1 orang siswa yang belum mencapai kriteria penilaian kraetivitas siswa yaitu $75 \%$.

Hasil refleksi pada siklus II ini dirinci sebagai berikut:

1. Rasa ingin tahu Siswa semakin meningkat dapat dilihat dari siswa yang selalu memperhatikan saat guru menjelaskan bagaimana langkah-langkah melipat origami.

2. Kreatifitas siswa meningkat dengan sangat cepat dapat dilihat dari siswa mulai bisa membuat berbagai macam bentuk benda dari kertas origami

3. Siswa menunjukkan ketekunnannya dalam membuat kreasi yang mereka buat bersama guru maupun kreasi sendiri.

4. Siswa memiliki kemauan yang tinggi untuk belajar membuat kreasi dari kertas origami dilihat dari siswa yang selalu meminta kertas origami pada guru.

\section{Pembahasan PeneIitian}

Penelitian tentang meningkatkan kreativitas siswa dengan menggunakan media kertas origami pada pembelajaran tematik tema 2 sub tema 3 di kelas 1 SDN 90/II Talang Pantai telah selesai dilaksanakan. Hasil penelitian tersebut membuktikan bahwa dengan menggunakan Media kertas origami pada tema 2 sub tema 3 yaitu gemar menggambar di kelas I menunjukkan adanya perubahan yang signifikan pada peningkatan kreativitas siswa. Peubahan tersebut dapat dilihat dari data prasiklus, siklus I dan siklus II.

Pada prasiklus atau tes awal dapat kita lihat bahwa perkembangan kreativitas siswa belum terlihat dan masih sangat kurang untuk kriteria nilai yang ditetapkan. Pada awal tes persentase 
siswa yang belum mencapai kriteria penileian yaitu $84 \%$ dari 16 siswa, dan siswa yang sudah mendekati kriteria penialaian yaitu 3 orang denga persentase $16 \%$, dengan demikian pada prasiklus dapat dikatakan bahwa peningkatan kreativitas siswa belum meningkat. Dan untuk meningkatkan hasil kreativitas siswa peneliti melalukan siklus berikutnya untuk melihat perkembangan siswa dalam berkreasi.

Setelah peneliti melakukan penelitian siklus I, kreativitas siswa sudah mulai terlihat di tandai dengan siswa yang sudah mulai memiliki rasa ingin tahu yang tinggi, sehingga muncul ide untuk berkreasi dengan menggunakan kertas origami meskipun masih dibantu oleh guru. Dan hasil presentasi pada siklus I pada siswa yang sudah mencapai kriteria penilaian kreativitas meningkat menjadi 68\% dari 13 orang siswa, sedangkan sisanya untuk siswa yang belum mencapai kriteria penilaian kreativitas yaitu ada 6 siswa dengan persentase $42 \%$. Di siklus ini dapat kita lihat berapa persen peningktannya dari prasiklus ke siklus 1, yaitu meningkat sekitar 52\% dan nilai ini belum begitu maksimal dan masih dibawah kriteria nilai yang sudah ditetapkan sehingga peneliti harus melanjutkan penelitian pada siklus II.

Dan pada siklus II terjadi perubahan yang begitu cepat. siswa yang awalnya masih memerlukan bantuan guru, disiklus II siswa bisa dikatakan tidak ada lagi yang meminta bantuan guru untuk melipat kertas origami ataupun tidak lagi yang meminta arahan dari guru untuk menunjukkan langkah-langkahnya dalam melipat kertas origami yang sudah mereka pelajari. Dan dikarnakan juga siswa sudah bisa membuat sendiri kreasi dari kertas origami. Sehingga angka presentase di siklus II ini meningkat secara drastis, yaitu dari 19 siswa ada 18 siswa yag sudah menunujukkan kreasinya dalam meningkatkan kreativitas dengan persentase 95\% dan hanya 1 orang siswa lagi yang belum menunjukkan perkembangan dirinya dalam meningkatkan kreativitas yaitu dengan persentase $5 \%$.

Maka dari penjabaran diatas telah dapat disimpulkan bahwa pada setiap siklus yang dilakukan oleh peneliti mengalami peningkatan dan perubahan yang signifikan pada peningkatan kreativitas siswa sehingga siswa telah mencapai kriteria penilaian 
kreativitas yang telah ditetapkan yaitu $75 \%$. Untuk lebih jelasnya kita lihat pada diagram berikut :

\section{Gambar 4}

Diagram Hasil Penilaian Kreativitas Siswa pada Prasiklus, siklus I Dan II

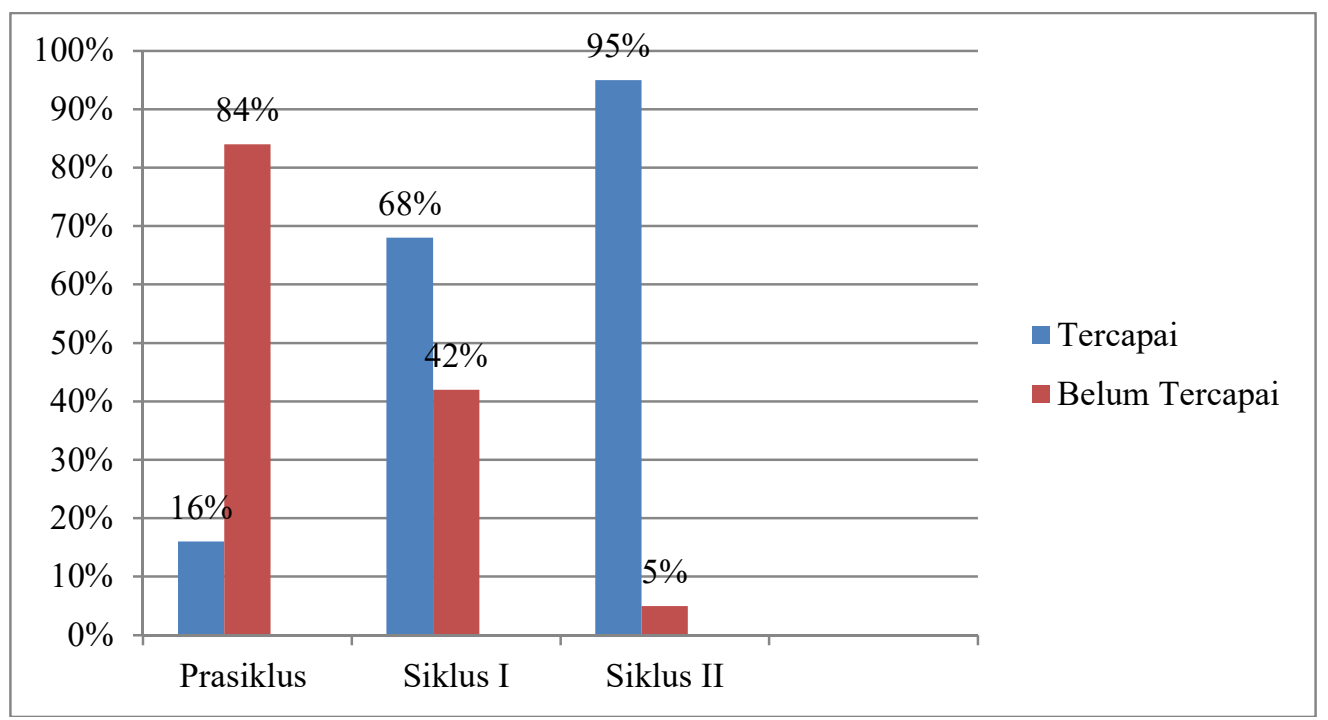

\section{PENUTUP}

Berdasarkan pembahasan pada bab sebelumnya, maka dapat disimpulkan bahwa penggunaan media kertas origami dapat Meningkatkan kreativitas siswa pada pembelajaran temetik di kelas I SDN 90/II Talang Pantai. Hal ini dapat dilihat dari penelitian yang menunjukkan bahwa perkembangan kreativitas peserta didik yang mengalami peningkatan.

1. Pada prasiklus siswa yang Belum mencapai kriteria penilaian yaitu sebanyak 16 orang siswa dari 19 orang siswa dengan nilai persentase yaitu $84 \%$ yang belum mencapai kriteria penilaian kreativitas, sedangkan siswa yang mendekati atau dengan 
penilaian cukup baik yaitu ada 3 oarang siswa dengan persentase $16 \%$.

2. Pada siklus I siswa mengalami peningkatan yang begitu cepat dari 3 orang siswa menjadi 13 orang siswa dengan nilai persentase $68 \%$. Sedangkan siswa dengan nilai cukup baik menurun menjadi 6 orang atau 42\%. penurunan Ini dikarnakan ada beberapa anak yang sudah bisa melipat kertas origami sendiri dan bisa mengikuti langkah-langkahnya dengan benar meskipun masih dibantu oleh guru. Setelah melaksanakan siklus 1 peneliti masih harus melanjutkan ke siklus II dikarnakan siswa belum mencapai kriteria penilian.

3. Pada siklus II, terjadi peningkatan yang begitu memuaskan peneliti dan guru, karna pada siklus II ini siswa hampir 100\% mencapai ketuntasan. Dari 19 orang siswa yang telah mencapai kriteria penilaian yaitu 18 orang siswa dengan nilai persentase mencapai $95 \%$ dan siswa yang belum meningkatkan kreativitasnya hanya satu orang siswa dengan persentase yaitu $5 \%$. telah sesuai dengan indikator tingkat pencapaian yakni 75\% sebanyak 18 siswa berhasil meningkatkan kreativitasnya dengan menggunakan media kertas origami. Maka dapat penulis simpulkan bahwa penggunaan media kertas origami dapat Meningkatkan kreativitas siswa pada pembelajaran tematik tema 2 sub tema 3 di kelas I SDN 90/II Talang Pantai.

\section{Daftar Pustaka}

Dirman dan Cicih Juarsih, kegiatan pembelajaran yang mendidik, Jakarta: PT Rineka Cipta, 2014, cet.1.

Hamzah B. Uno dan Nurdin Mohamad. Belajar dengan pendekatan PAILKEM: Pembelajran Aktif, Inovatif,Lingkungan, Kreatif, Efektif, Menarik. Jakarta: PT Bumi Aksara, 2011.

Hamzah B. Uno. Model pembelajaran, menciptakan proses belajar mengajar yang kreatif dan efektif, Jakarta: Bumi Aksara, 2012, cet.9. 
Hasnida. Media pembelajaran kreatif mendukung pengajaran pada anak usia dini, Jakarta Timur: PT Luxima Metro Media, 2014, Cet.1.

Haziah Ans dan Mastris Radyamas. let's play ORIGAMI: Cerdas dan Kreatif dengan kertas. Surakarta: indiva Media Kreasi, 2015.

Iif Khoiru Ahmadi dan Sofan Amri. Pengembangan \& Model pembelajran Tematik Integratif. Jakarta:PT. Prestasi Pustakaraya, 2014.

Lila Putri Dewanti," Meningkatkan Kreativitas Anak Melalui Permainan Origami Pada Siswa Sekolah Dasar". (Skripsi, Fakultas Psikologi Universitas Muhammadiyah Malang, 2017).

M. Fadillah. implementasi kurikulum 2013 dalam pembelajran SD/MI, SMP/MTS, \& SMA/MA.Yogyakarta: Ar-Ruzz Media, 2014, cet. 1.

Mona Novita. PTK Tidak Horor, Surabaya : CV. Pustaka Media Guru, 2018.

Ngalim Purwanto. Prinsip-prinsip dan Teknik Evaluasi Pengajaran, Bandung: PT Remaja Rosdakarya, 2006, cet.13.

Nunuk Suryani. et.al. media pembelajaran inovatif dan pengembangannya, Bandung: PT Remaja Rosdakarya, 2018.

Rulam Ahmadi. Pengantar Pendidikan: Asas dan Filsafat Pendidikan, Yogyakarta: Ar-ruzz Media, 2014, cet.1.

Sa'dun Akbar,et.al., implementasi pembelajaran tematik di sekolah dasar, Bandung: PT Remaja Rosdakarya, 2016, cet. 1.

Sukardi. metode penelitian pendidikan tindakan kelas implementasi dan pengembangannya, Jakarta: PT Bumi Aksara, 2013, cet.2.

Yeni Rachmawati dan Euis Kerniati. Strategi pengembagan Kreativitas pada Anak, Jakarta: Prenanda Media Group, 2011, cet.2. 